Јасмина М. АХМЕТАГИЋ ${ }^{*}$ Институт за српску културу Приштина - Лепосавић
Оригинални научни рад

Примљен: 21. 9. 2020.

Прихваћен: 25. 2. 2021.

\title{
ПСИХОЛОШКИ ПРИСТУПИ ПРОЗИ ИВЕ АНДРИЋА
}

\begin{abstract}
Осветљавајући фројдовска, јунговска, лакановска, те антрополошка и егзистенцијално-психолошка/феноменолошка тумачења прозе Иве Андрића, указали смо на централне оријентације психолошких приступа делу нашег нобеловца, на њихове резултате и слабости. Психолошки приступ књижевности посматра се овде као један од релевантних интердисциплинарних метода, насупрот његовом учесталом поистовећивању са редукционистичким психоаналитичким тумачењем и предубеђењу да се тако утемељене анализе односе искључиво на садржај дела. Психолошки приступ Андрићевој прози ослоњен на конкретне психолошке теорије, утврдили смо, дао је уз не тако бројна редукционистичка читања, која књижевним делом илуструју психолошке теорије, и неке од најрелевантнијих резултата. Текст доноси критичко читање тих интерпретација и указује на могуће подручје будућих истраживања, пре свега уз помоћ најмање коришћене, али потенцијално плодоносне Селф психологије Хајнца Кохута.

Кључне речи: Иво Андрић, психолошки приступ, психоанализа, архетипови, Фројд, Јунг, снови, Лакан, Селф психологија.
\end{abstract}

Под психолошким приступом књижевном делу подразумевамо интердисциплинарно тумачење које се у осветљавању књижевног дела користи конкретним сазнањима психолошке науке и ослања на психолошке теорије, фокусирајући се на психологију ликова и њихове мотивације. Без разумевања међусобних односа карактера у делу не можемо разумети ни структуру у случајевима у којима је „структурални распоред (...) резултат саодноса психичких комплекса" јунака (Кордић 1975: 94). Па ипак је још актуелно потцењивање психолошких приступа, услед њиховог поистовећивања са ортодоксним психоаналитичким читањем ${ }^{1}$, те предубеђења да се тако утемељене анализе односе искључиво на садржај дела. Полазишта, резултате и слабости

\footnotetext{
*ahjasmina@yahoo.com

${ }^{1}$ Иако су се све психолошке школе које надаље помињемо развиле из психоанализе, па се о њима често говори као о различитим фазама њеног развоја, овде ћемо - немајући простор за елаборацију тог и у психологији нерешеног питања - под психоаналитичким приступом подразумевати само ортодоксну, Фројдову анализу. Сва феминистичка, па чак и постколонијална
} 
психолошких приступа прози Иве Андрића, те указивање на могући простор будућих истраживања, осветлићемо кроз неколико карактеристичних примера, колико нам дозвољава крајње сужен простор за ову опсежну и комплексну тему.

Књижево дело у коме је присутно такво богатство људских судбина и изразитих јунака, какво је Андрићево (већ велики број његових наслова ставља централни карактер у први план), није могло искључити њихову психолошку анализу ни у класичним књижевнотеоријским и естетичким приступима. Међутим, психолошки приступ Андрићевој прози ослоњен на конкретне психолошке теорије, који је био далеко ређи, дао је уз не тако бројна редукционистичка читања, која изневеравају књижевно дело, и неке од најрелевантнијих резултата.

Никола Милошевић, ,јједан од зачетника новије српске психолошке критике", Андрићевом делу приступа имајући на уму неколико универзалних „антрополошких закона” (в. Палавестра 2007: 75), попут отуђења и аутодеструкције, а заправо психолошки приступ продубљује егзистенцијалистичко-филозофским и клони се једностране оријентације на несвесно, што је једна од основних заблуда редукционистичке психолошке критике. Критика усмерена на несвесно може доспети до релевантних и проверљивих резултата само анализом ониричког света јунака и испитивањем несвесних мотивација о којима књижевни текст пружа податке, тј. које се могу прозрети иза конкретних понашања, исказа и односа протагониста. Улазећи у психолошки простор ликова Н. Милошевић се држи граница света постављеног делом и стога и доспева до књижевно релевантних, синтетичких увида у Андрићеву антропологију, истичући пишчеву „способност за откривање унутрашње логике људских поступака” (1964: 132), те „дубоку и префињену логику психолошке мотивације" (1996: 178). Међутим, чак и овај тумач залази у простор биографског тумачења, тврдећи да су психолошки механизми одбране мотивисали извесне Андрићеве књижевне изборе (Милошевић 1978: 159), те разумевајући пишчев критички однос према биографском методу као последицу и функцију „механизма одбране” (1978: 154).

Пре изузетак него правило у приступу Андрићевој прози представља психоаналитичко читање Аникиних времена из пера Радомана Кордића и Војина Матића, чему ћемо посветити већу пажњу како бисмо илустровали подређивање књижевнотеоријског приступа априорно постављеном психоаналитичком тумачењу, те на конкретним примерима показали могуће путеве потпуније анализе.

Кордић, питајући се „зашто Андрић уопште казује причу о попу Вујадину пре историје Аникиних времена?” (1975: 102) уочава да је структура приповетке одређена психолошком повезаношћу јунака, јер део о судбини попа Вујадина представља „противтежу архетипској реалности Аникиног доба” (1975: 95). Мада доспева до значајних увида - пре свега у анализи Михаило-

и имаголошка читања на трагу су психолошких приступа, као и сва промишљања Другости и идентитета, али би таква разматрања увелико превазишла оквире овог текста. 
вог односа према Аники и Крстиници, а јунак их поистовећује кроз „пројекцију зле, фалусне мајке" (Кордић 1975: 115) - слабости његове интерпретације почивају на психоаналитичком бекграунду, видљивом у пројављивању усвојених, априорних концепата, какав је мотив инцеста, који је у тумачењу слабо одржив, а који ће доминирати, показаћемо, и Кордићевим тумачењем Жене на камену. Фокусирајући се на мотив инцеста, уместо на активирање архетипа Велике мајке, тумач Михаилово искуство мотивише само индивидуално несвесним и тиме практично сужава семантику Андрићеве приповетке.

Разлоге Вујадиновог понашања, који „нису једнозначни и једносмерни” (Кордић 1975: 95) тумач поједностављује примењујући Фројдову технику тумачења снова на сцену у којој Вујадин воајерски посматра понашање мушкараца и жена на заравни. Закључујући да „цела слика има симболичку вредност, а сваки од њених елемената је, као у сну, симбол за себе” (1975: 99), Кордић се држи Фројдовог тумачења снова, које је пречесто симболе сводило на знакове. Стога, уместо тумачења скривених значења, критичар прибегава преименовању: зараван представља кревет, број три (број окупљених мушкараца), као и пушка и нож, јесу „симболи мушкости”, а заправо су тек произвољни означитељи. Да се Кордић одлучио за Јунгово тумачење снова, на овом би месту применио метод амплификације (проширивање посматране слике аналогним садржајма из митова, бајки и легенди), а то би га морало одвести од сцене коју посматра поп Вујадин кроз прозор - реч је о жетви, која има обредни карактер - ка миту, што Кордић увића и сам („Треба рећи да сејање и сабирање жетве имају сексуализовано архетипско значење"2 - 1975: 100), али се ипак брзо окреће психоаналитичким мотивима кастрације и инцеста. Да је Вујадин усамљеник, удовац који поступно копни, а његова мушкост природно опада, знамо из онога што је о јунаку казао приповедач - с друге стране, о његовим конфликтним жељама говори његово понашање. Оно што је потребно објаснити, посредством психолошког знања, то је настанак психозе, мотивација његових присилних несвесних садржаја. Вујадинов „страх од женског” је очевидан, а то што га Кордић тумачи искључиво као кастрациони страх Фројдово је наслеђе, односно поједностављена слика сложене игре привлачности и међусобне одбојности полова. „Страх од женског” је архетипски мотив, и захтевао би тумачење у контексту архетипова Јунговог колективног, па и Сондијевог фамилијарно несвесног (поп Мелентије, Јакша и Вујадин узорци су фамилијарног низа). Већ тврдња да пушка симболизује мушкост подсећа на оно психоаналитичко тумачење Камијевог Странциа, по коме је пуцањ на плажи симболичка ејакулација (Брок 1993: 93).

Примена Фројдове технике снова на сцену коју на заравни посматра Вујадин води Кордића прекомпликованом и неконзистентном тумачењу, те комбинаторици бројчаних низова (у поигравању са симболиком броја три), из којег ништа не следи од значаја за причу, а чини се да аутор одустаје од

\footnotetext{
${ }^{2}$ Сексуалност је повезана са обредима сејања жита и жетвом у бројним митовима, а симболика земље која се сеје и земље која даје плод у тесној је вези са природним циклусима женског оплођења и рађања.
} 
најдубљег смисла коме га воде властите речи јер већ има припремљену, априорну, фројдовску тезу (када се у хришћанској култури помене ,један који је тројица”, па још када се то учини у вези са свештениковом психозом - „Вујадин је три мушкарца" - онда би ту било простора за тумачење осећања јунакове омнипотентности, на пример). Уосталом, „употреба психоаналитичког жаргона и Фројдове листе симбола која стоји у прилогу његовог Тумачења снова из 1914. основни су разлози који су утицали на лошу репутацију психоаналитичких читања књижевности" (Холанд 1990: 35).

Да Аника има вредност архетипа, и то да оживљава архетип Еве (што je, према Јунгу, један од четири архетипа женског), те да у њу касабалије „пројицирају своје забрањене жеље” (1975: 106), као и читање драме Аникиних времена у (фројдовском) контексту сукоба природе и културе, све су то вредни доприноси Кордићевог психолошког читања. Међутим, архетип је по својој природи амбивалентан и то је његово суштинско својство, тако да је пре типична но ексклузивна Аникина двозначност, а ипак, њену актуелну ситуацију Кордић тумачи у контексту „разрешења примарног конфликта” (1975: 111), те пренебрегава чињеницу да је њен преображај наступио нагло и да је њено самоуништење и самоповређивање повезано са Михаиловим одбијањем, на шта упућују и Н. Милошевић и Д. Стојановић.

Указујући на квалитет касабалијске „нормалности” коју поремећује Аника, Д. Стојановић у свом егзистенцијалистичко-феноменолошком читању Аникиних времена рехабилитује Аникину изузетност и неизбежну психолошку одређеност том изузетношћу: „После неуспеха да с Михаилом оствари љубав, остаје она у власти нарцистичке опседнутости собом, која се даље продубљује” (Стојановић 2003б: 131). Повезаност приче о попу Вујадину и Аники, Стојановић налази у феномену мржње, штавише, паралелизам који налази са „Тијанином узбуном" води га закључку да су, са становишта феноменологије мржње сва времена Аникина времена. Н. Милошевић још конкретније констатује да поп Вујадин представља „крајњи, патолошки заправо шизофрени случај (...) унутрашњег расцепа" (1964: 141). Чињеница је да Вујадин доспева до психозе, као што је чињеница да у жене пројектује властита осећања мржње, а видећи у њима прогонитеље (иако он за њима јури), овај јунак је параноичар, као и Мустафа Маџар, и припада оном типу Андрићевих поремећених јунака, у чијем би тумачењу сигурно велики допринос дала најмање коришћена, а по нашем мишљењу потенцијално најплоднија у тумачењу књижевности тзв. Селф психологија Хајнца Кохута (в. Ахметагић 2011, 2012).

Психоаналитичар и ерудита Војин Матић у тексту „Искуство прасцене код Андрића" даје једно у великој мери арбитрарно тумачење, стављајући у сам наслов психоаналитички термин: „Слика коју је описао Андрић, у психоанализи је позната као присуствовање такозваној прасцени, сексуалном односу између родитеља у првих годину-две дана живота" (1983: 228). Промишљајући лик попа Вујадина, Матић на питање како је писац могао „корак по корак, реконструисати развој лудила свога јунака (...) тако да нас убеди да човек заиста може тако полудети" (1983: 227), одговара биографском претпоставком: наш је писац, наслућује Матић, „у младости проживео 
таква стања" (1983: 228). Не налазећи да између првог дела о томе како је полудео поп Вујадин и другог дела приповетке о Аникином лудовању, њеном завођењу и потчињавању мушкараца, постоји дубља веза - сматрајући да их је Андрић тек „овлашно и неразумљиво повезао споредном личношћу деде” (1983: 229), Матић закључује да је прича о Аники илустрација оправданости страхова попа Вујадина, будући да Андрић „није успео да себи одговори на питање шта се десило његовом главном јунаку" (1983: 229). Из Матићевог тумачења следи да је сам Андрић, изношењем Аникине историје, потврдио најдубље Вујадинове страхове, показујући колико жена изванредне лепоте може бити опасна. То би онда значило, ако следимо такво тумачење, да се сам Андрић оглашава у оном исказу свог јунака да у свакој жени постоји ђаво кога треба убити радом или рађањем, чиме се превиђа и семантика приповетке и Андрићева поетика и улога лепоте у њој.

Полазећи од тога да су сви јунаци Аникиних времена трауматизовани, Б. Катушић у свом лакановском читању („Аника и велики Други”) помно кроз текст приповетке истражује све сигнале који указују на „расцјеп између онога што се говори и онога што се исказује” (2017: 348), утврђујући константну и на свим нивоима постојећу удвојеност протагониста, њихову подељеност у идентитетском и културолошком смислу, те прелази на наратолошку анализу, показујући колико је важно да питање које се поставља пред књижевноуметничким делом извире из њега самог.

Када је реч о психоаналитичком читању Жене на камену Кордићев промашај је потпун онолико колико је потпуна његова верност Фројду. У тексту „Либидинозна структура језика (Жена на камену Иве Андрића)” аутор се обраћа психоаналитичкој теорији за разумевање и оних мотива које би спонтано и без вишка психоанализе највероватније протумачио исправно. Уместо упитаности над тим шта значи један еротски догађај између петнаестогодишње девојке и педесетогодишњег јуродивог Матије, догађај који се сав заснива на игри гледања и завођења, па још шта тај догађај значи за Марту која га се сећа у часу када се приближава Матијиним годинама и опседнута је знацима старења - Кордић полази од питања шта значи целокупан Мартин живот с обзиром на инцестуозни карактер догађаја, који му се чини неупитан.

Тумачећи еротско искуство са Матијом у контексту Мартине фиксације на оца, као инцестуозни избор љубавног објекта, Кордић у целини пренебрегава јунакињин доживљај. Тако превиђа да је Андрић психолошки мотивисао чињеницу да се једна професионално остварена, али емотивно усамљена жена, управо на мору суочава са сећањем на тренутак у коме је открила моћ своје лепоте, себе као жену. Ако еротско задовољство које почива на аутоеротском уживању значи „само обнављање једног ранијег догађаја” (1975: 217), онда је оно темељно потцењено, јер је час у коме девојчица спознаје снагу и моћ властитог пола и лепоте право мало откровење. Значај еротског искуства којег се сећа Марта у зрелим годинама прецизно одређује Д. Стојановић: „Она је у његовим очима ту ватру видела и упила је за сва времена, као сопствени еманирани садржај, који јој је он, доживљен, вратио. У њему, видела је она најлепшу себе” (2003a: 74). 
Матија као „померени циљ жеље” (1975: 218), Марта као лик са Електриним комплексом, те поклањање нове, беле мужевљеве кошуље за Матинију сахрану као поклањање своје женскости, невиности (и то на темељу њене белине, која је, према Фројду, симбол жене), све је то доследно изневеравање животног контекста јунакиње. Полазаћи од погрешног аксиома, тумач каузално увезује све мотиве њеног живота и фалсификује Андрићеву причу, говорећи о ономе што је у њој одсутно (нпр. удубљује се у то какав је био Мартин „прави човек”).

Мартино размишљање о старењу у Кордићевој интерпретацији постаје само супститут за нерешени несвесни конфликт са којим она не жели да се суочи, као да старење за лепотицу, оперску диву, није релевантан проблем у култури већ тада опседнутој телом. Све то открива границу психолошке критике, која би у овом случају требало да објасни зашто је старење тако велики проблем за Марту, а не да порицањем тог проблема измени и саму тему приче. Хомоеротизам Кордић опажа и код Вујадина, као и код Марте, иако за то приче не нуде аргументе, а јунакињину анксиозност назива параноидним стањем (1975: 322), што је омашка на коју га наводи снажан фокус на психоаналитичке конструкте.

Попут Фројда, који је испричао причу сваке жене (завист због пениса, фиксација на оца, ривализовање са мајком), и Кордић индивидуализовану јунакињу раствара у општости. Ако тумачење идентичног сна мора да се разликује у зависности од личности сневача и његовог животног контекста, на шта је упозорио Јунг, и тумачење епизоде које се сећа јунакиња битно зависи од њене личности и актуелне животне ситуације. Намеће се закључак да је први услов психолошког приступа књижевности емпатија, која је кључни значај и добила са развојем Селф психологије и дефинисана је као „покушај особе да доживи унутрашњи живот друге док симултано задржава став објективног посматрача" (Кохут 2013: 175). Без емпатијског проосећања које подразумева разумевање јунакове ситуације и из његове личне перспективе (а што актуализује категорије доживљаја и уживљавања у процесу рецепције дела), психолошки приступ потврђује психолошке теорије на штету књижевности.

Колико је тачније запажање да истакнута улога оца у Мартином животу значи пре свега усвајање мушке визуре и система вредности, те погледа на свет и себе из мушке перспективе. Мада наслов текста „Опсесија телом као последица прихватања мушке визуре жене: Анрићева Жена на камену” упућује на феминистичко читање Андрића, интерпретација Д. Поповић Срдановић је психолошки конзистентна и чврсто се држи текста, те је у том смислу mindful close reading, за шта се пледира у новијим промишљањима односа књижевности и психологије (в. Бојд 2014).

Психолошки приступи који се ослањају на Јунга донели су неке од најзначајних увида у Андрићево дело. Јелена, жена које нема, протумачена је у контексту Јунгових архетипова, као архетип Аниме, што је радикалан искорак у односу на интерпретације које су у тој непостојећој, а жељеној и свеприсутној жени виделе „флуидну утвару” (Ређеп, према Башић 2011: 17), фантазијско биће, духа као у „готским причама о духовима и аветињским 
привиђењима" (Палавестра 1981: 121). Не само да Јелену Анте Башић разумева као Аниму, односно унутрашњу жену пишчеве психе, него Ex ponto и Немире сматра круцијалним делима за постављање тезе о Андрићу као писцу чије је дело могуће ишчитавати у кључу Јунгове аналитичке психологије (2011: 7), а „Кулу” узима за пример приповетке „која говори о иницијацији и сусрету са несвесним" (2011: 99), али то опсежније не елаборира. Потрагу за Јеленом можемо „проматрати и као потрагу митске и психичке нарави: с једне стране, у питању је митски образац који пратимо још од Одисејева напуштања Итаке, у потрази за самоостварењем, а с друге - (...) потрага појединца за властитом другом несвјесном и потиснутом половицом" (Башић 2011: 13). Анима је архетип одговоран за уметничку страну личности, о чему је писао и Иван Настовић (2012), утврђујући да Јелена представља Андрићеву „унутрашњу идеалну слику женског бића (...) енергетско језгро његовог стваралаштва” (2012: 231), јер је Анима, према Јунгу и „'архетип живота и креације’, односно феномен живота у психи мушкарца” (2012: 242).

Дубинско психолошко читање Андрићеве Госпођице даје Петер Тирген, тврдећи да роман доноси „сажет психолошки портрет јунакиње као појединца" (1996: 287). Посебно је значајно његово пионирско тумачење јунакињиног сна у коме се јавља побуна „против ланаца очевог завештања” (1996: 303), са очигледним ослањањем на Јунгово тумачење снова. Тумач указује на одбрамбене механизме који владају психом Рајке Радаковић и открива схему Електриног комплекса који управља њеним односом са оцем (1996: 292). Мада знаке маскулинизације ове јунакиње ишчитава у кључу њене психичке крутости (1996: 302), Тирген дословно тумачи сва испољавања овог лика у складу са постављеном схемом тумачења, те тако и упадљиве знаке параноидности - Госпођица је мономанијакалан карактер, а мономанија је „општи термин за оно што данас зовемо параноја или делузиони поремећај” (Тротер 2001: 18) - ишчитава у контексту њене „несвесне заштите девичанства”, односно „опседнутост силовањем” (1996: 297). И Фелисити Рослин (1983) указује на инцестуозну природу односа Рајке Радаковић са оцем, мада потпуније психолошко знање и обраћање архетиповима пре говори о инцестуозној психолошкој констелацији а не конкретном односу као инцестуозном.

Лакановски приступ Госпођици донеће танано нијансирање између конкретног оца и Оца као фигуре културе, те тако имплицитно већ садржи критички став према покушајима да се јунакињин однос са оцем објасни мотивом инцестуозности. Посредством Лакана, психолошки свет јунакиње биће сагледан у својој двострукости: Рајка Радаковић, „ратница против Закона Оца, покорава се фантазму властитог Оца и његовог закона” (Јовановић 2017: 216). Андрићевим јунакињама је уопште посвећено доста критичке пажње: женски карактери су класификовани на различите начине (од Б. Новаковића до Т. Ливерсејџ), а у интерпретативном смислу реч је о спорадичним опаскама општег психолошког типа пре но о утемељеном и развијеном психолошком приступу. Тако ће један тумач исправно приметити да се у Лотикином лику очитава архетип Велике мајке (Ивановић Ковачевић 2017: 197), али такво опажање у контексту који не укључује доследан јунговски 
приступ добија статус етикете и стога и не води дубљем разумевању јунакиње, него опстаје у метафоричној функцији (ни Ливерсејџ, ослањајући се на Јунга, не објашњава деловање архетипа Сенке у психологији Госпођице, иако на то упућује). Психолошка тумачења Андрићеве прозе указују на нужност дубљег познавања психолошких теорија које се примењују, како би се избегла неселективна и неадекватна употреба термина. Уосталом, психолошке приступе у интерпретацији треба користити онда када сама грађа нуди материјал за такву обраду, а њихова примена поуздано води проширеном и продубљеном разумевању књижевног дела.

Докле год постоје књижевни јунаци који немају довољан увид у себе, ма колико иначе били сложени и потпуно развијени, њихова психолошка анализа ће бити важан посао књижевног интерпретатора. С друге стране, упркос илузији објективности, начин на који перципирамо једно дело одређен је нашим осећањима, системом вредности, „па и идејама о томе како треба читати дело" (Холанд 1990: 55-6), односно психологијом. Тако ће једно од постколонијалних читања Омерпаше Латаса утврдити хибридни идентитит централног јунака (Ивон 2012); посредством Селф психологије, међутим, утврђујемо да је Латас човек без својстава, лишен супстанцијалности. Пример не илуструје само очигледну разлику у суду, већ и то да ће процена које је тумачење истинитије неминовно зависити од референтног оквира тумача сусрету са књижевношћу осуђени смо на психологију. Стога се психолошки приступи не могу заобићи, али се могу учинити ваљанијим. Чак и важније од психолошке контекстуализације термина за једног тумача мора бити само питање које поставља књижевном делу - он мора бити спреман да одбаци теорију која му нуди одговоре и пре но што за само питање обезбеди адекватан сазнајни контекст.

\section{ЛИТЕРАТУРА}

Ахметагић 2011: J. Ahmetagić. Paradoks zlostavljanja: žena kao trofej. Priče o Narcisu zlostavljaču: zlostavljanje i književnost. Beograd: Službeni glasnik, 101-116.

Ахметагић 2012: Ј. Ахметагић, Баналност зла у причи „Бифе 'Титаник”, Свеске Задужбине Иве Андрића, 29, 244-259.

Башић 2011: A. Bašić, Andrićevo svjetlo iznad puta: poetika Ive Andrića iz aspekta Jungove analitičke psihologije, s posebnim osvrtom na pripovjetku „Jelena, žena koje nema” i ostale pojavne manifestacije Jelenine, Beograd: Službeni glasnik.

Бојд 2014: B. Boyd, Psychology and Literature: Mindful Close Reading, in: C.

Danta, H. Groth (eds.), Mindful Aesthetics: Literature and the Science of Mind, New York: Bloomsbury.

Брок 1993: Mersault the Straw Man, Studies in the Novel, spring 1993. Jstor. 15. 11. 2015. 
Ивон 2014: Ivon, K. Identitet bez identiteta (Ćamil između Istoka i Zapada), Croatica et Slavica Iadertina, 2012. Hrčak. 28. 08. 2020.

Ивановић Ковачевић 2017: M. Ivanović Kovačević, Andrićeva Rajka Radaković i Lotika kao antipodi, u: B. Tošović (ur.), Andrićeva Gospođica / Andrićs Fräulein, Andrić-Initiative. 10, Graz, Banja Luka, Beograd: Institut für Slawistik der Karl- Franzens-Universität Graz, Narodna i univerzitetska biblioteka Republike Srpske, Svet knjige, Nmlibris, 195-205.

Јовановић 2017: T. S. Jovanović, Andrićeva Gospođica u svetlu lakanovskih i postlakanovskih psihoanalitičkih teorija, u: B. Tošović (ur.), Andrićeva Gospođica / Andrićs Fräulein, Andrić-Initiative. 10, Graz, Banja Luka, Beograd: Institut für Slawistik der Karl- Franzens-Universität Graz, Narodna i univerzitetska biblioteka Republike Srpske, Svet knjige, Nmlibris, 213-222.

Катушић 2017: Б. Катушић, Аника и велики Други, Култура, бр. 14, 335-367. Кордић 1975: Р. Кордић, С оне стране структуре (Аникина времена Иве Андрића), Археологија књижевног дела, Београд: Просвета, 92-122.

Кордић 1975: Р. Кордић. Либидинозна структура језика (Жена на камену Иве Андрића), Археологија књижевног дела, Београд: Просвета, 205-230.

Koхут 22013: H. Kohut, How does analysis cure, Chicago and London: The University of Chicago Press.

Ливерсејџ 2005: Т. Ливерсејџ, Женски ликови у делу Иве Андрића, Свеске Задужбине Иве Андрића, 22, 383-440.

Матић 1983: V. Matić, Iskustvo prascene kod Andrića, Psihologija mitske prošlosti, III, Beograd: Prosveta, 222-233.

Милошевић 1964: Н. Милошевић, Антрополошки вид Андрићевог књижевног стваралаштва, Антрополошки есеји, Београд: Нолит, 130-167.

Настовић 2012: И. Настовић, Јелена, жена које нема Иве Андрића у светлости дубинске психологије, Свеске Задужбине Иве Андрића, 29, 231-243.

Палавестра 1981: P. Palavestra, Skriveni pesnik: prilog kritičkoj biografiji Ive Andrića, Beograd: Slovo ljubve.

Палавестра 2007: П. Палавестра, Андрићеви критичари V, Свеске Задужбине Иве Андрића, 24, 57-89.

Поповић-Срдановић 2010: Д. Поповић-Срдановић, Опсесија телом као последица прихватања мушке визуре жене: Андрићева Жена на камену, Тело и одело у култури Срба и Бугара, Ниш: Филозофски факултет, 167-178.

Рослин 1983: F. Roslin, Ivo Andrić i Gospođica, Sveske Zadužbine Ive Andrića, 2, 227-248.

Стојановић 2003а: Д. Стојановић, Очи које тако гледају: Жена на камену, Лепа бића Иве Андрића. Подгорица, Нови Сад: ЦИД, Платонеум, 62-75.

Стојановић 2003б: Д. Стојановић. Лепота и мржња: Аникина времена, Лепа бића Иве Андрића, Подгорица, Нови Сад: ЦИД, Платонеум, 87-149.

Тирген 1996: P. Tirgen, Roman Gospođica Ive Andrića: psihologija, simbolika, poređenje teksta, Sveske Zadužbine Ive Andrića, 12, 281-305.

Tротер 2001: D. Trotter, Paranoid modernism, New York: Oxford University Press. Холанд 1990: N. Holland, Holland's Guide to Psychoanalytic Psychology and Literature-and-Psychology, New York: Oxford University Press. 
Jasmina M. Ahmetagić

\title{
PSYCHOLOGICAL APPROACHES TO IVO ANDRIĆ' PROSE
}

\begin{abstract}
Summary
Under psychological approach we imply the interpretations which, having Andrić's heroes as a central interest, strived towards explanations of specific psychological knowledges and theories. Our focus is on Freudian, Jungian, Lacanian, anthropological and existential-psychological/phenomenological reading, but we paid the most attention to the intersection of critical views on Anika's Times and The Woman on the Rock. Critical interpretation of psychoanalitical readings by R. Kordić and D. Matić are here a base around which the more relevant interpretations are collected. It enabled us to point out the drawbacks and limitations of psychological approaches in a concise and concrete way, neccessary for such a comprehensive topic. We have determined that the one of the basic misconceptions of reductionist psychological critiques is the orientation toward unconsciousness: relevant and verifiable results can be gained only by inquiring protagonists' oniric world and unconsciouss motivations behind their behavior, statements and relationships. As we have shown, Jungian oriented deep psychological interpretations of Jelena, Woman Who is Not and The Woman From Sarajevo testify about that. With few reductionist readings, psychological approach to Andrić's prose gave us some of the most fruitful results.
\end{abstract}

